\title{
Development and Full Validation of a Stability- indicating HPLC Method for the Determination of the Anticancer Drug Temozolomide in Pharmaceutical Form
}

\author{
Anti-kanser İlaç Temozolomidin Farmasötik Formundan Miktar Tayini \\ için Ters Faz Sıvı Kromatografisi Yönteminin Geliştirilmesi, Validasyonu ve \\ Stabilite Çalışması
}

\author{
(D) Evin KAPÇAK, (D) Eda Hayriye ŞATANA-KARA* \\ Gazi University, Faculty of Pharmacy, Department of Analytical Chemistry, Ankara, Turkey
}

\begin{abstract}
Objectives: In the present study, an accurate, precise and simple method has been developed for the determination of TMZ in its pharmaceutical form by using HPLC.

Materials and Methods: An HPLC method with a DAD was validated according to ICH guidelines. A C18 column (150x4.6 mm. i.d., 5 um particle size) and an aqueous acetate buffer $(0.02 \mathrm{M})$-acetonitrile $(90: 10, \mathrm{v} / \mathrm{v})(\mathrm{pH} 4.5)$ as a mobile phase were used.

Results: The linear range and LOD value were $5-100 \mu \mathrm{g} / \mathrm{mL}$ and $0.02 \mu \mathrm{g} / \mathrm{mL}$, respectively. The accuracy of the method was determined using a recovery test and found as $98.8-100.3 \%$. In addition, forced degradation studies of the drug were also performed in bulk drug samples to demonstrate the specificity and stability-indicating. Degradation studies under acidic, basic, oxidative, and thermal degradation conditions were applied. Conclusion: The proposed method could be applied successfully for the determination and identification of the degradation of the drug. Key words: Temozolomide, HPLC, validation, determination, degradation
\end{abstract}

Öz

Amaç: Bu çalışmada TMZ'nin farmasötik formundan tayini için doğru, kesin ve basit bir yüksek basınçlı sıvı kromatografi yöntemi geliştirilmiştir. Gereç ve Yöntemler: DAD dedektörlü HPLC yöntemi ICH kurallarına göre valide edilmiştir. C18 kolon (150x4.6 mm. i.d., $5 \mu \mathrm{m}$ tanecik boyutu) ve hareketli faz olarak sulu asetat tampon (0.02 M)- asetonitril $(90: 10, \mathrm{~h} / \mathrm{h})(\mathrm{pH} 4.5)$ karışımı kullanılmıştır.

Bulgular: Doğrusal aralık ve LOD değerleri sırası ile 5-100 $\mu \mathrm{g} / \mathrm{mL}$ and $0.02 \mu \mathrm{g} / \mathrm{mL}$ 'dir. Yöntemin doğruluğu geri kazanım yöntemi ile belirlenmiş ve \%98.8-100.3 olarak bulunmuştur. Bu çalışmaların yanı sıra bozunma çalışmaları yapılmıştır. Bozunma çalışmaları asidik, bazik, oksidatif ve termal bozunma şartlarında gerçekleștirilmiștir.

Sonuç: Önerilen metod ilacın miktar tayini ve bozunma çalışması için başarı ile uygulanmıştır.

Anahtar kelimeler: Temozolomid, HPLC, validasyon, miktar tayini, bozunma

\section{INTRODUCTION}

Temozolomide (TMZ), 4-methyl-5-oxo-2,3,4,6,8-pentazabicyclo [4.3.0]nona-2,7,9-triene-9-carboxamide, is an oral anticancer drug. It belongs to the alkylating agent class and is used for the treatment of brain cancer such as glioblastoma multiforme.,2
The antitumor effect of TMZ depends on its ability to alkylate/ methylate DNA. This methylation damages DNA and triggers the death of tumor cells. TMZ is a prodrug and an imidazotetrazine derivative of the dacarbazine, 5-(3-dimethyltriazen-1-yl)imidazo-4-carboxamide (DTIC). TMZ demonstrates better 
antitumor activity and a better safety profile in preclinical assessments.,4 The antitumor activity of the drug depends on linear triazine, 5-(3-methyltriazen-1-yl)-imidazo-4carboxamide (MTIC). DTIC is metabolically converted to MTIC in the liver, whereas TMZ is degradated chemically to MTIC at physiologic $\mathrm{pH} .{ }^{5} \mathrm{MTIC}$ shows a cytotoxic effect due to alkylation at the $\mathrm{O} 6$ and $\mathrm{N} 7$ positions of guanine. After this process, MTIC converts itself to 5(4)-aminoimidazole-4(5)-carboxamide (AIC) (Figure 1). ${ }^{6,7}$ In a literature survey, different techniques exist for the analysis of TMZ. Ultraviolet (UV) spectrophotometric methods have been described for the determination of TMZ in pharmaceutical formulations. ${ }^{8-11}$ Only two electrochemical studies based on an investigation of the electrochemical behavior of TMZ exist in the literature..$^{12,13}$ In addition, chromatography with UV ${ }^{14-21}$ and mass spectrometry detection ${ }^{22-24}$ were the most common techniques used for the separation and determination of $T M Z$, its metabolites, and degradation products. The aim of this research was to optimize and develop a simple, rapid, economical, precise and accurate, reproducible, and fully validated high-performance liquid chromatography (HPLC) method with good detection limits for the estimation of TMZ in a pharmaceutical preparation. Forced degradation studies are also presented to show the stability-indicating capacity of the developed HPLC method. The stability tests for the developed method were performed according to International Conference on Harmonization (ICH) guidelines. ${ }^{25,26}$

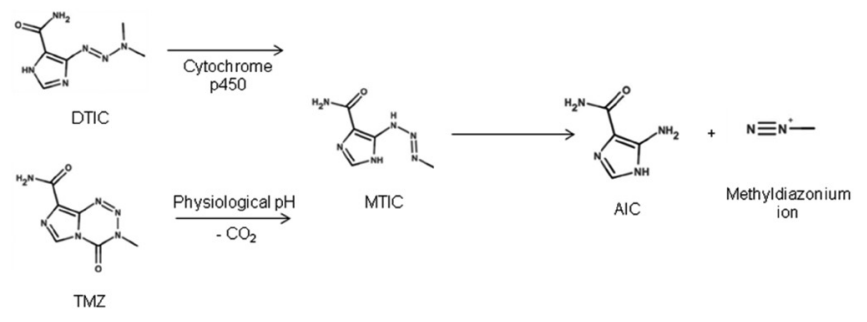

Figure 1. Chemical structures and conversion process of temozolomide MTIC: 5-(3-methyltriazen-1-yl)-imidazo-4-carboxamide, DTIC: 5-(3-dimethyltriazen1-yl)-imidazo-4-carboxamide, AIC: 5(4)-aminoimidazole-4(5)-carboxamide, TMZ: Temozolomide

\section{EXPERIMENTAL}

\section{Chemical and reagents}

TMZ and dose form were purchased from Sigma-Aldrich and local suppliers, respectively. Chromatographic-grade acetonitrile and analytical grade acetic acid, sodium acetate, phosphoric acid, boric acid, $\mathrm{HCl}$, and $\mathrm{NaOH}$ were obtained from Merck (Darmstadt, Germany). Double-distilled water with conductivity lower than $0.05 \mu \mathrm{S} / \mathrm{cm}$ was used to prepare the mobile phase solutions. The mobile phase used in HPLC was an aqueous acetate buffer (0.02 M)-acetonitrile (90:10, v/v) ( $\mathrm{pH}$ 4.5). After mixing, the mobile phase was degassed. For the preparation of the standard TMZ stock solution, $20.0 \mathrm{mg}$ TMZ was accurately weighed and dissolved in mobile phase in a 100 $\mathrm{mL}$ volumetric flask and then adjusted to $100.0 \mathrm{~mL}$ with the same solution. For stabilization experiments, a similar quantity of TMZ was dissolved in $100 \mathrm{~mL}$ deionized water. Standard solutions in the range of $5.0-100.0 \mu \mathrm{g} / \mathrm{mL}$ were prepared using the appropriate dilution of the stock solution. A calibration curve was drawn using the peak area values versus these concentration values at the optimized conditions.

\section{Instrumentation}

The HPLC system consisted of a Agilent series 1260 solvent delivery system with an Agilent 1260 diode-array detector (DAD) system. An ACE C18 column (150x4.6 mm. i.d., $5 \mu \mathrm{m}$ particle size) was used. Mobile phase filtration was performed using an Erich Wiegand GmbH type N 022 AN 18 vacuum pump with all tech $47 \mathrm{~mm}, 0.45 \mathrm{~m}$ filter paper. Bondelin Sonorex RK $100 \mathrm{H}$ was used as a degasser. The typical operating conditions were as follows: flow rate, $0.8 \mathrm{~mL} / \mathrm{min}$; operating temperature, $30^{\circ} \mathrm{C}$; injection volume, $30 \mu \mathrm{L}$.

\section{Analysis of pharmaceutical form}

The average mass of 10 capsules was determined. Capsule contents were accurately weighed. A definite amount of the powder was transferred to a $250 \mathrm{~mL}$ volumetric flask and the volume was adjusted to the mark with the mobile phase. The solution was sonicated in an ultrasonicator for $20 \mathrm{~min}$ and the solution was filtered. The appropriate volume of the filtrate was diluted with the mobile phase prior to analysis. In order to determine the TMZ content of the capsule, TMZ standard solutions were injected and the calibration curve was obtained as the peak area versus the concentration. The sample solution, $30 \mu \mathrm{L}$, was injected, and the detection was at $260 \mathrm{~nm}$. The amount of TMZ in a capsule was determined using the calibration curve.

\section{Degradation studies}

Degradation studies were attempted for stress conditions by acidic hydrolysis, alkaline hydrolysis, oxidation, and heat in an oven (at $100^{\circ} \mathrm{C}$ ), to evaluate the ability of the proposed method to separate TMZ from its degradation product. The peak purity test was performed for TMZ peaks by using a DAD in the stress samples. The optimized method was used to study the forced degradation behavior of TMZ and may also applied in the stability testing of pharmaceuticals. An appropriate blank was injected before analysis of the forced samples.

The reactions were conducted with $20 \mu \mathrm{g} / \mathrm{mL}$ of TMZ. The stress conditions were as follows:

- Acidic hydrolysis: Drug solution in $1 \mathrm{M} \mathrm{HCl}$ was exposed at $80^{\circ} \mathrm{C}$ for $60 \mathrm{~min}$

- Alkaline hydrolysis: Drug solution in $1 \mathrm{M} \mathrm{NaOH}$ was exposed $80^{\circ} \mathrm{C}$ for $60 \mathrm{~min}$.

- Oxidative condition: Drug solutions in $3 \% \mathrm{H}_{2} \mathrm{O}_{2}$ were stored at $80^{\circ} \mathrm{C}$ for $60 \mathrm{~min}$

- Thermal stress: Bulk drugs were subjected to dry heat at $100^{\circ} \mathrm{C}$ for $24 \mathrm{hr}$.

In addition, TMZ is highly unstable in alkaline solutions and relatively stable under acidic $\mathrm{pH}$ conditions. Therefore, a TMZ stock solution was also prepared in deionized water to provide 
degradation in the working environment and chromatograms were recorded.

There was no need for ethics committee approval for this study.

\section{RESULTS AND DISCUSSION}

\section{Optimization of chromatographic conditions}

The column, mobile phase composition, $\mathrm{pH}$, flow rate, and column temperature were tested to optimize the separation conditions. In order to evaluate the effect of the column on the separation, C8 and C18 columns were tested. A well-shaped symmetrical peak was obtained with the C18 column. Different buffer solutions have been tested to characterize the drug at different $\mathrm{pH}$ values. For this purpose, acetate buffer $(\mathrm{pH} 3.5$ 5.5), phosphate buffer ( $\mathrm{pH}$ 6.0-8.0), borate buffer ( $\mathrm{pH} 9.0$ ), $0.1 \mathrm{M} \mathrm{HCl}$, and $0.1 \mathrm{M} \mathrm{NaOH}$ solutions were tried. According to the literature, $\mathrm{TMZ}$ is stable in medium at $\mathrm{pH}<5$. In addition, obtained results from absorbance spectra show that highest absorbance value was achieved at $\mathrm{pH}<5$. Hence, $\mathrm{pH} 4.5$ acetate buffer was selected. The mobile phase acetate buffer (0.02 M)acetonitrile (90:10, v/v) ( $\mathrm{pH} 4.5)$ was most found suitable for $\mathrm{TMZ}$ analysis using DAD detection at $260 \mathrm{~nm}$ at $30^{\circ} \mathrm{C}$. When methanol was used as an organic phase, the peak of TMZ had a shoulder, and the tailing factor of the peak was more than 2. However, when using acetonitrile, a sharp symmetrical peak was obtained. For the optimization of the organic phase ratio, $10 \%, 20 \%$, and $30 \%$ acetonitrile ratios were tried. When the organic phase ratio was increased above $10 \%$, the retention time was shortened such that the separation in the TMZ peak could not be sufficient and tailing at the peak was observed. When the ratio of acetonitrile was $10 \%$, retention improved and a symmetrical peak was observed. Temperatures between $15^{\circ} \mathrm{C}$ and $40^{\circ} \mathrm{C}$ were scanned to examine the effect of temperature. It was observed that temperature affected both the separation and the peak symmetries. Hence, $30^{\circ} \mathrm{C}$ was selected as the optimized temperature. It was observed that the flow rate had little effect on the resolution but changed the retention time to a great extent. Different flow rates, $0.8 \mathrm{~mL} /$ $\mathrm{min} ; 1 \mathrm{~mL} / \mathrm{min}$, and $1.3 \mathrm{~mL} / \mathrm{min}$ were tried and optimum results were obtained at $0.8 \mathrm{~mL} / \mathrm{min}$. Optimized chromatographic conditions and a typical LC chromatogram are given in Table 1 and Figure $2 a$, respectively. After determining the best

Table 1. Optimized chromatographic conditions

\begin{tabular}{ll} 
Mobile phase & $\begin{array}{l}\text { Acetate buffer }(0.02 \mathrm{M}) \text {-acetonitrile } \\
(90: 10, \mathrm{v} / \mathrm{v})(\mathrm{pH} 4.5)\end{array}$ \\
\hline Column & $\begin{array}{l}\text { ACE C18 }(150 \times 4.6 \mathrm{~mm} . \text { i.d., } 5 \mu \mathrm{m} \\
\text { particle size })\end{array}$ \\
\hline Flow rate & $0.8 \mathrm{~mL} / \mathrm{min}$ \\
\hline Injection volume & $30 \mu \mathrm{L}$ \\
\hline Column temperature & $30^{\circ} \mathrm{C}$ \\
\hline Detection wavelength & $260 \mathrm{~nm}$ \\
\hline Retention time & $3.5 \mathrm{~min}$ \\
\hline
\end{tabular}

conditions, a satisfactory chromatographic peak resolution was obtained in a short analysis time. Under the optimized operating conditions, the retention time corresponding to TMZ was 3.5 min, being extremely stable among injections. Using these optimum conditions, shorter analysis times, and higher accuracy and selectivity were obtained. The proposed method was successfully used for the determination of TMZ in its dose form and related data on the specificity for their estimation in the presence of their degradation compounds are reported (Figure $2 \mathrm{~b}$ ). The proposed study was easily used with mixtures of stressed samples with drug degradation. The resolution between the degradation products and the drug peak was satisfactory.

\section{Validation procedures of the methods}

A system suitability test can be defined as a test to specify that a method can generate acceptable accuracy and precision results. According to the USP, system suitability tests were performed prior to analysis. ${ }^{27}$ Hence, system suitability for the proposed method was evaluated. For this purpose, test parameters such as capacity factor, theoretical plate number, retention time, symmetry factor, selectivity, and relative standard deviation (RSD) \% of the peak area for repetitive injections were calculated. For the method to be valid, at least two of these criteria were required to demonstrate system suitability for the proposed method. The results obtained from system suitability tests were found within acceptable limits and in agreement with the USP requirements. The parameters obtained from the system suitability analysis are presented in Table 2.

\section{Linearity}

The linearity of the detector responses for TMZ was determined using peak area versus concentration. The linearity was obtained in the range of $5.0-100 \mu \mathrm{g} / \mathrm{mL}$ at a detection wavelength $260 \mathrm{~nm}$, with a correlation coefficient ( $r$ ) of 0.9998 .

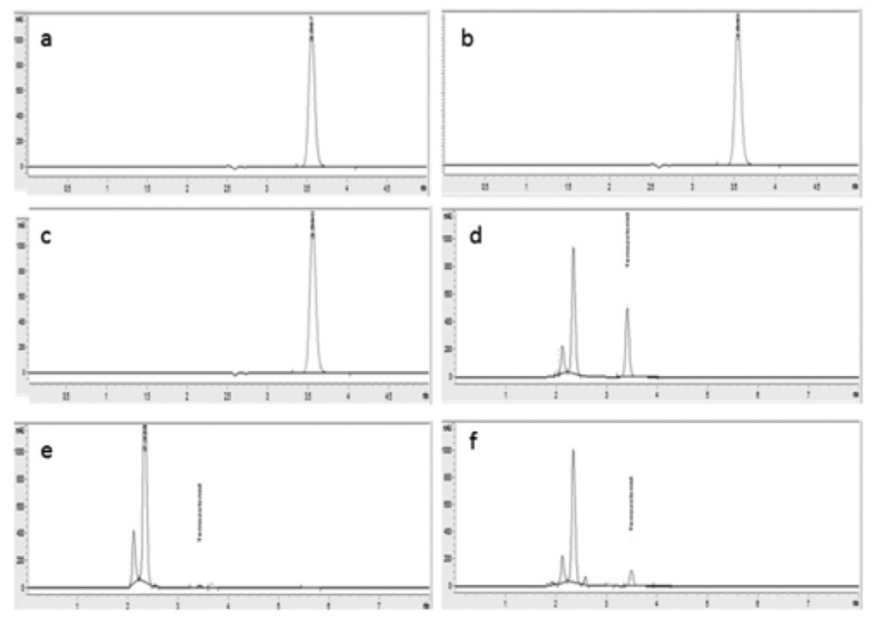

Figure 2. Chromatograms of (a) $20 \mu \mathrm{g} / \mathrm{mL}$ TMZ standard solution and (b) $20 \mu \mathrm{g} / \mathrm{mL}$ TMZ capsule solution. Chromatograms of the stress studies under (c) acidic hydrolysis, (d) alkaline hydrolysis, (e) oxidation and ( $f$ ) dry heat

TMZ: Temozolomide 
The good linearity of the calibration graph and the negligible scatter of experimental points were evident by the values of the correlation coefficient and standard deviation. The analytical features of calibration graph are listed in Table 3.

\section{Limit of detection and limit of quantification}

Several approaches are given in the $\mathrm{ICH}$ guidelines to determine the limit of detection (LOD) and limit of quantification (LOQ). $L O D$ and $L O Q$ were calculated from the equations of $L O D=3.3$ $\mathrm{s} / \mathrm{m}$ and $L O Q=10 \mathrm{~s} / \mathrm{m}^{28}$ where $\mathrm{s}$ is the standard deviation of responses and $m$ is the slope of the calibration curve (Table 3 ).

\section{Table 2. System suitability test parameters}

\begin{tabular}{ll} 
Parameters & Calculated values \\
\hline Theoretical plate number $(\mathrm{N})$ & 7964 \\
\hline Capacity factor $\left(\mathrm{k}^{\prime}\right)$ & 1.393 \\
\hline Tailing factor $(\mathrm{T})$ & 1.055 \\
\hline Resolution $\left(\mathrm{R}_{\mathrm{S}}\right)$ & 5.05 \\
\hline Symmetry factor & 0.99 \\
\hline RSD\% of peak area & 0.08 \\
\hline Retention time $\left(\mathrm{t}_{\mathrm{r}}\right)$ & 3.5 \\
\hline
\end{tabular}

RSD: Relative standard deviation

Table 3. Regression data of the calibration lines for quantitative determination of temozolomide by high-performance liquid chromatography

\begin{tabular}{ll} 
Linearity range $(\mu \mathrm{g} / \mathrm{mL})$ & $5-100$ \\
\hline Slope & 52.27 \\
\hline Intercept & 22.31 \\
\hline Correlation coefficient & 0.9998 \\
\hline SE of slope & 0.16 \\
\hline SE of intercept & 7.52 \\
\hline $\mathrm{LOD}(\mu \mathrm{g} / \mathrm{mL})$ & 0.02 \\
\hline $\mathrm{LOQ}(\mu \mathrm{g} / \mathrm{mL})$ & 0.06 \\
\hline
\end{tabular}

LOD: Limit of detection, LOQ: Limit of quantification

Table 4. The results of intra-day and inter-day precision

\begin{tabular}{ll}
\hline Inter-day precision $(\mu \mathrm{g} / \mathrm{mL})$ & $(R S D \%)^{*}$ \\
\hline 20.04 & 0.12 \\
\hline 25.05 & 0.03 \\
\hline 30.06 & 0.04 \\
\hline Intra-day precision $(\mu \mathrm{g} / \mathrm{mL})$ & $(R S D \%)^{*}$ \\
\hline 20.04 & 0.08 \\
\hline 25.05 & 0.11 \\
\hline 30.06 & 0.08 \\
\hline
\end{tabular}

*Each value is the mean of six experiments, RSD: Relative standard deviation

\section{Precision}

System repeatability was determined through six replicate applications at three different concentrations (20.04, 25.05, and $30.06 \mu \mathrm{g} / \mathrm{mL}$ ) on the same day (intra-day precision) and measurements of the peak area for the active compound. Inter-day precision was assessed by the assay of similar concentration sample sets on three different days. The results summarized in Table 4 indicate a high degree of precision for the proposed method.

\section{Accuracy}

In order to find out the accuracy of the proposed method, recovery studies were performed by spiking the sample of a capsule with an appropriate amount of a stock solution of TMZ. Recovery of the method was determined by spiking the marketed sample with 50\%, 100\%, and 150\% standard solutions. As can be seen in Table 5 , relatively high recovery values were obtained using the proposed method. These high recovery values proved the accuracy of the developed method.

\section{Robustness}

Robustness can be defined as the capacity of a developed method to remain unaffected by analysis parameters. Hence, the results of the organic phase ratio, $\mathrm{pH}$ value, temperature, flow rate, and wavelength parameters were evaluated to determine the robustness of the proposed method. The robustness tests were performed at $20 \mu \mathrm{g} / \mathrm{mL}$ of TMZ. The analyzed conditions, obtained results, and RSD\% values are shown in Table 6. The results were evaluated statistically using the Friedman test. As seen from the table, the calculated values of all parameters were smaller than the theoretical value, which indicated that minor changes in the system did not lead to significant differences in peak areas. Therefore, it can be said that the developed method was stable and robust.

\section{Forced degradation studies}

To present the stability and indicate the capability of the developed HPLC method, forced degradation studies were

Table 5. Results of the assay and the recovery analysis of temozolomide in pharmaceutical dose forms via high-performance liquid chromatography

\begin{tabular}{lllll} 
Labeled claim (mg) & 5.00 & & \\
\hline Amount found (mg) & $5.00 \pm 0.004$ & & \\
\hline RSD (\%) & 0.30 & & & \\
\hline Bias (\%) & 0.00 & & & \\
\hline Recovery results $^{\mathrm{b}}$ & \multicolumn{1}{l}{ Found } & $\begin{array}{l}\text { Recovery } \\
(\%)\end{array}$ & $\begin{array}{l}\text { RSD } \\
\%\end{array}$ & $\begin{array}{l}\text { Bias } \\
\text { (\%) }\end{array}$ \\
\hline Added (mg) & (mg)* & (m) & & \\
\hline 2.5 & $2.47 \pm 0.02$ & 98.90 & 0.26 & 1.2 \\
\hline 5 & $5.02 \pm 0.15$ & 100.40 & 0.13 & -0.4 \\
\hline 7.5 & $7.47 \pm 0.21$ & 99.65 & 0.55 & 0.4 \\
\hline
\end{tabular}

${ }^{a}$ Each value is the mean of five experiments, ${ }^{b}$ Each value is the mean of three experiments, *Each value is the mean of three experiments, RSD: Relative standard deviation 
performed. Degradation studies were performed as mentioned in the experimental section. Degradation experiments were designed using acidic hydrolysis, alkaline hydrolysis, hydrogen peroxide, and dry heat. The stock solutions of the compounds were diluted with $\mathrm{HCl}, \mathrm{NaOH}$, and $\mathrm{H}_{2} \mathrm{O}_{2}$ to $20 \mu \mathrm{g} / \mathrm{mL}$ and left for $1 \mathrm{~h}$. Degradation peaks were separated from the main peaks. When applying drastic conditions, TMZ was stable in acidic media, whereas it was clearly degraded in basic media, and with heat and oxidation. Degradation percentage values were calculated as a ratio of the peak areas of untreated drug

Table 6. Statistical comparison of robustness results of highperformance liquid chromatography method

\begin{tabular}{|c|c|c|c|}
\hline Parameters & & Peak area* & RSD \% \\
\hline \multirow[t]{3}{*}{ Organic phase ratio (\%) } & 8 & 1101.8 & 0.15 \\
\hline & 10 & 1100.3 & 0.18 \\
\hline & 12 & 1099.4 & 0.18 \\
\hline \multicolumn{4}{|l|}{$\chi_{\text {r(calculated })}^{2}=1.5$} \\
\hline \multirow[t]{3}{*}{$\mathrm{pH}$ value } & 4.3 & 1096.4 & 0.15 \\
\hline & 4.5 & 1092.2 & 0.18 \\
\hline & 4.7 & 1094.4 & 0.18 \\
\hline \multicolumn{4}{|l|}{$\chi_{\text {r(calculated })}^{2}=3.1$} \\
\hline \multirow[t]{3}{*}{ Temperature $\left({ }^{\circ} \mathrm{C}\right)$} & 27 & 1101.1 & 0.07 \\
\hline & 30 & 1100.3 & 0.12 \\
\hline & 33 & 1101.8 & 0.09 \\
\hline \multicolumn{4}{|l|}{$\chi_{\text {r(calculated })}^{2}=2.6$} \\
\hline \multirow[t]{3}{*}{ Flow rate $(\mathrm{mL} / \mathrm{min})$} & 0.7 & 1102.9 & 0.15 \\
\hline & 0.8 & 1100.2 & 0.14 \\
\hline & 0.9 & 1099.9 & 0.17 \\
\hline \multicolumn{4}{|l|}{$\chi_{r \text { (calculated) }}^{2}=4.2$} \\
\hline \multirow[t]{3}{*}{ Wavelength (nm) } & 258 & 1098.1 & 0.11 \\
\hline & 260 & 1101 & 0.18 \\
\hline & 262 & 1098.8 & 0.11 \\
\hline
\end{tabular}

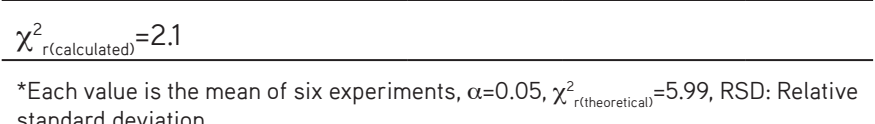

Table 7. The results of forced stress conditions of temozolomide

\begin{tabular}{lll} 
The response of hard stress conditions & $\begin{array}{l}\text { Degradation of } \\
\text { compound (\%) }\end{array}$ & RSD (\%) \\
\hline $\mathrm{HCl}(1 \mathrm{M})$ & - & - \\
\hline $\mathrm{NaOH}(1 \mathrm{M})$ & 89 & 0.12 \\
\hline $\mathrm{H}_{2} \mathrm{O}_{2}(3 \%)$ & 55 & 0.08 \\
\hline Heating $\left(100^{\circ} \mathrm{C}\right)$ & 98 & 0.21 \\
\hline
\end{tabular}

${ }^{*}$ Each value is the mean of three experiments, RSD: Relative standard deviation solution and treated solutions. The chromatograms are shown in Figure 2c- $f$ and degradation percentages were tabulated after each treatment, as shown in Table 7. In addition, it has been shown in the literature that $\mathrm{TMZ}$ chemically degrades to MTIC both in vivo and in vitro at physiologic $\mathrm{pH}(\mathrm{pH} 6-7) .{ }^{29}$ The degradation product, MTIC, is disrupted by the formation of the methyldiazonium ion and AIC as shown in Figure 1. In order to evaluate degradation, the stock TMZ solution was prepared in deionized water and the required dilutions were made with water again (Figure 3a). The $\mathrm{pH}$ value of the prepared aqueous stock solution was measured as about 8.5. This value causes degradation of TMZ. As seen from Figure 3, a new peak appeared at $2.2 \mathrm{~min}$. A 6-hour stability test was performed for chromatographic studies. When chromatograms of the diluted solution of deionized water were examined, it was observed that the peak area of TMZ decreased with time and the peak of the unknown species increased without changes in the retention times of both species (Table 8). On the other hand, in the solution in which the diluent was made using the $\mathrm{pH} 4.5$ acetate buffer, there was no change in the values of the TMZ and the unknown species (Figure $3 \mathrm{~b}$ and Table 8 ). Compared with the spectra of the TMZ, MTIC, and AIC species obtained from the literature, ${ }^{30}$ and the three-dimensional spectrum obtained from the DAD detector, it is suggested that the unknown species belongs to AIC.

\section{Application of the HPLC method for the analysis of commercial formulations}

In the present work, the application of the developed method for the determination of TMZ in pharmaceutical samples was presented. Evaluation of pharmaceutical formulations was performed by using the calibration curve method. Calibration graphs were constructed by measuring the peak areas obtained at these concentrations under optimized conditions. The proposed methods were applied to the determination of TMZ in its pharmaceutical form Temodal ${ }^{\circledR}$ (Schering-Plough, Belgium), labeled as $5 \mathrm{mg}$ TMZ. This is a simple procedure that can be used without any sample extraction, evaporation, or filtration. No interfering peaks were observed from any of the inactive ingredients of the assayed preparations. The precision and
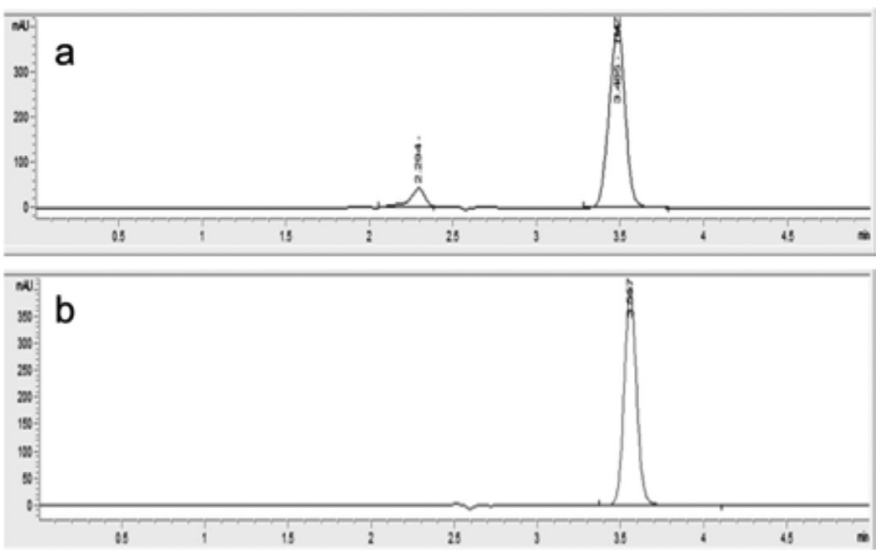

Figure 3. Chromatograms of $20 \mu \mathrm{g} / \mathrm{mL}$ temozolomide standard solutions prepared in (a) deionized water and (b) pH 4.5 acetate buffer 
Table 8. Peak areas changes of temozolomide and unknown species

\begin{tabular}{|c|c|c|c|c|c|c|c|c|}
\hline \multicolumn{5}{|c|}{ Prepared in deionized water } & \multicolumn{4}{|c|}{ Prepared in pH 4.5 acetate buffer } \\
\hline Time $(\min )$ & $\begin{array}{l}\text { Unknown peak } \\
\text { area }\end{array}$ & Unknown $t_{R}$ & $\begin{array}{l}\text { TMZ peak } \\
\text { area }\end{array}$ & TMZ $t_{R}$ & $\begin{array}{l}\text { Unknown peak } \\
\text { area }\end{array}$ & Unknown $t_{R}$ & TMZ peak area & $T M Z t_{R}$ \\
\hline 0 & 99.1 & 2.3 & 1084.6 & 3.5 & 19.9 & 2.3 & 1126.3 & 3.7 \\
\hline 30 & 110.6 & 2.3 & 1080.3 & 3.5 & 20.8 & 2.3 & 1123.5 & 3.7 \\
\hline 60 & 133.1 & 2.3 & 1076.0 & 3.5 & 20.5 & 2.3 & 1125.7 & 3.7 \\
\hline 120 & 463.7 & 2.3 & 905.0 & 3.5 & 20.1 & 2.3 & 1124.1 & 3.7 \\
\hline 180 & 1133.8 & 2.3 & 729.4 & 3.5 & 20.2 & 2.3 & 1126.8 & 3.7 \\
\hline 240 & 1314.4 & 2.3 & 358.5 & 3.5 & 20.6 & 2.3 & 1124.2 & 3.7 \\
\hline 300 & 1695.0 & 2.3 & 314.8 & 3.5 & 20.4 & 2.3 & 1124.9 & 3.7 \\
\hline 360 & 1699.0 & 2.3 & 311.2 & 3.5 & 20.4 & 2.3 & 1121.7 & 3.7 \\
\hline
\end{tabular}

TMZ: Temozolomide

accuracy results showed that the proposed methods could be applied for the determination of TMZ in pharmaceutical formulations without any interference effect of the inactive ingredients. The use of all of the proposed method was verified by means of replicate estimations of pharmaceutical preparations and the results obtained were evaluated statistically (Table 5).

\section{CONCLUSIONS}

The stability-indicating HPLC method was fully validated according to $\mathrm{ICH}$ guidelines and was presented for the determination of TMZ in capsule formulation, which offers numerous advantages, such as rapidity, use of minimum amounts of organic solvents, simplicity, low cost, ease of operation, and high selectivity. Good recoveries, high reproducibility, and interference-free chromatograms were also achieved. A high percentage of recovery results showed that the proposed methods were free from interferences of commonly used excipients and additives in the formulation.

Conflict of Interest: No conflict of interest was declared by the authors.

\section{REFERENCES}

1. Wang Z, Hu P, Tang F, Lian H, Chen X, Zhang Y, He X, Liu W, Xie C. HDAC6 promotes cell proliferation and confers resistance to temozolomide in glioblastoma. Cancer Lett. 2016;379:134-142.

2. Lee SY. Temozolomide resistance in glioblastoma multiforme. Genes \& Diseases. 2016;3:198-210.

3. Stevens MF, Hickman JA, Langdon SP, Chubb D, Vickers L, Stone R, Baig G, Goddard C, Gibson NW, Slack JA, Newton C, Lunt E, Fizames C, Lavelle $\mathrm{F}$. Antitumor activity and pharmacokinetics in mice of 8-carbamoyl3-methyl-imidazo[5,1-d]-1,2,3,5-tetrazin-4(3H)-one (CCRG 81045; M \& B 39831), a novel drug with potential as an alternative to dacarbazine. Cancer Res. 1987;47:5846-5852

4. Tsang LL, Quarterman CP, Gescher A, Slack JA. Comparison of the cytotoxicity in vitro of temozolomide and dacarbazine, prodrugs of 3-methyl-(triazen-1-yl) imidazole-4-carboxamide. Cancer Chemother Pharmacol. 1991;27:342-346.
5. Wei JH, Zhou RH, Peng Y, Liu YC. Studies on the binding properties of temozolomide with DNA. Asian J Chem. 2013;25:2597-2600.

6. Hartley JA, Gibson NW, Kohn KW, Mattes WB. DNA sequence selectivity of guanine-N7 alkylation by three antitumor chloroethylating agents. Cancer Res. 1986;46:1943-1947.

7. Meer L, Janzer RC, Kleihues P, Kolar GF. In vivo metabolism and reaction with DNA of the cytostatic agent, 5-(3,3-dimethyl-1-triazeno)imidazole4-carboxamide (DTIC). Biochem Pharmacol. 1986;35:3243-3247.

8. Madhu M, Raj NRS, Swathi V, Yasmeen R, Ishaq BM. Development and validation of UV spectroscopic method for the estimation of temozolomide in capsule dosage form. Int J Biol Pharm Res. 2014;5:701705.

9. Razak A, Omshanthi B, Suresh V, Obulamma P. Development and validation of UV method of temozolomide in bulk and capsule formulation. Int J Biol Pharm Res. 2013;4:1419-1423.

10. Ishaq M, Hindustan AH, Muneer S, Parveen S, Fahmida B. Analytical method development and validation for the estimation of temozolomide in phosphate buffer in pH 2.0 as a solvent by UV spectroscopy. Int Res J Pharm. 2014;5:17-20.

11. Sankar DG, Latha PVM, Kumar BA, Babu PJ. UV spectrophotometric determination of temozolomide and gemcitabine. Asian $\mathrm{J}$ Chem. 2007;19:1605-1607.

12. Lopes IC, Oliveira SCB, Brett AMO. Temozolomide chemical degradation to 5-aminoimidazole-4-carboxamide-electrochemical study. J Electroanal Chem. 2013;704:183-189.

13. Ghalkhani M, Fernandes IPG, Oliveira SCB, Shahrokhian S, Shahrokhian $\mathrm{S}$, Oliveira-Brett AM. Electrochemical redox behaviour of temozolomide using a glassy carbon electrode. Electroanalysis. 2010;22:2633-2640.

14. Khan A, Imam SS, Aqil M, Sultana Y, Ali A, Khan K. Design of experiment based validated stability indicating RP-HPLC method of temozolomide in bulk and pharmaceutical dosage forms. Beni-Suef Univ J Appl Sci. 2016;5:402-408.

15. Gilant E, Kaza M, Szlagovska A, Byczak K, Rudzki PJ. Validated HPLC method for determination of temozolomide in human plasma. Acta Pol Pharm. 2012;69:1347-1355.

16. Rao AL, Ramesh GT, Rao JVLNS. RP-HPLC analysis of temozolomide in pharmaceutical dosage forms. Asian J Chem. 2010;22:5067-5071. 
17. Shen F, Decosterd LA, Gander M, Leyvraz S, Biollax J, Lejeune F. Determination of temozolomide in human plasma and urine by highperformance liquid chromatography after solid-phase extraction. J Chromatogr B Biomed Appl. 1995;19:291-300.

18. Kim HK, Lin CC, Parker D, Veals J, Lim J, Likhari P, Statkevich P, Marco A, Nomeir AA. High-performance liquid chromatographic determination and stability of 5-(3-methyltriazen-1-yl)-imidazo-4-carboximide, the biologically active product of the antitumor agent temozolomide, in human plasma. J Chromatogr B Biomed Sci Appl. 1997;703:225-233.

19. Pallerla S, Prabhakar B. Bio analytical method development and validation of temozolomide in rat plasma using RP-HPLC method. Int J Pharm Sci Res. 2016;7:1298-1301.

20. Attari Z, Kumar L, Rao CM, Koteshwara KB. Validation of a sensitive and robust reversed phase-HPLC method for determination of temozolomide. Lat Am J Pharm. 2016;35:967-971.

21. Saravanan G, Ravikumar M, Jadhav MJ, Suryanarayana MV, Someswararao N, Acharyulu PVR. A stability indicating LC assay and degradation behaviour of temozolomide drug substances. Chromatographia. 2007;66:291-294.

22. Chowdhury SK, Laudicina D, Blumenkrantz N, Wirth M, Alton KB. An LC:MS:MS method for the quantitation of MTIC (5-(3-N-methyltriazen-1$\mathrm{yl}$ )-imidazole-4-carboxamide), a bioconversion product of Temozolomide, in rat and dog plasma. J Pharm Biomed Anal. 1999;19:659-668.
23. Zhang Y, Sun Y, HE Q, Han J, Shi M, Fang C, Fawcett JP, Yang Y, Gu J. Simultaneous determination of temozolomide acid and its hexyl ester in plasma by LC-MS/MS: application to the first pharmacokinetic study of temozolomide hexyl ester in rats. Anal Methods. 2014;6:8973-8978.

24. Negreira N, Mastroianni N, Lopez de Alda M, Barcelo D. Multianalyte determination of 24 cytostatics and metabolites by liquid chromatographyelectrospray-tandem mass spectrometry and study of their stability and optimum storage conditions in aqueous solution. Talanta. 2013;116:290-299.

25. ICH Guideline (Q2A) (R1) Validation of analytical procedures: text and methodology IFPMA, Geneva, 2005.

26. ICH Guideline (Q1AR) Stability testing of new drug substances and products International Conference on harmonization IFPMA, Geneva, 2000.

27. McNally R. The United States Pharmacopoeia, 24th revision, Easton: Taunton; MA; 2000.

28. Swartz ME, Krull IS. Analytical Development and Validation; Marcel Dekker Inc.; New York; 1997.

29. Jedynak L, Puchalska M, Zezula M, Laszcz M, Luniewskib W, Zagrodzka J. Stability of sample solution as a crucial point during HPLC determination of chemical purity of temozolomide drug substance. J Pharm Biomed Anal. 2013;83:19-27.

30. Khalilian MH, Mirzaei S, Taherpour AA. The simulation of UV spectroscopy and electronic analysis of temozolomide and dacarbazine chemical decomposition to their metabolites. J Mol Model. 2016;22:270. 